\title{
Differential pharmacology and clinical utility of preservative-free tafluprost in the treatment of ocular hypertension and glaucoma
}

This article was published in the following Dove Press journal:

Clinical Ophthalmology

4 May 2012

Number of times this article has been viewed

\author{
Sıtkı Samet Ermiș \\ Faculty of Medicine, Balıkesir \\ University, Tıp Fakültesi, Çagıș \\ Kampüsü, Balıkesir, Turkey
}

Correspondence: Sıtkı Samet Ermiș Faculty of Medicine, Balıkesir University, Tıp Fakültesi, Çagıș Kampüsü,

I0I45 Balıkesir, Turkey

Tel +905337737358

Email sametermis@hotmail.com
Abstract: Glaucoma is a chronic disease requiring lifelong treatment. Discomfort due to medications may affect patients' quality of life and may cause poor compliance, which leads to poor intraocular pressure control. To minimize the side effects of long-term treatment, preparations with lower benzalkonium chloride concentrations, preservative-free preparations and alternative preservatives have been developed and reported to have a lower rate of side effects. Tafluprost, launched on the ophthalmic market in 2008, is a new 16-phenoxy analogue of prostaglandin $\mathrm{F}_{2 \alpha}$, clinically used as an ocular hypotensive agent for the treatment of glaucoma and ocular hypertension. The safety and intraocular pressure-lowering efficacy of tafluprost has been demonstrated in various preclinical and clinical studies.

Keywords: tafluprost, AFP 168, glaucoma, intraocular pressure, preservative

Glaucoma is a group of diseases with a characteristic pattern of progressive optic neuropathy and a decrease in retinal sensitivity that cause visual loss. It is one of the most common causes of blindness worldwide. Due to aging of the population, the number of patients with glaucoma is expected to rise. It is a major public health problem and has economic consequences. Once the disease is diagnosed, treatment is required to stop progressive optic nerve damage. If glaucoma is not diagnosed and treated properly, it can lead to total and irreversible blindness.

The role of intraocular pressure (IOP) in glaucoma was suggested nearly 150 years ago and ocular hypotensive agents were used in treatment even before the exact mechanism by which they lowered IOP was understood. A large body of evidence has established the importance of IOP. ${ }^{1}$ Lowering IOP as much as possible improves the likelihood of delaying or halting the progression of optic nerve damage and visual field loss. ${ }^{2}$

Medical management is the first therapeutic approach to the treatment of glaucoma. Today, there is a large armamentarium of ocular hypotensive medications and physicians must consider various factors in determining the appropriate medication for patients. Efficacy, safety and tolerability, the mechanism of action for lowering IOP, compliance, and cost are important factors in drug treatment. The most commonly used criteria for evaluating efficacy is IOP decrease in the treated subjects. Control of IOP over a 24-hour period is also important; IOP must stay fairly constant. The side effects of medications must be evaluated for each patient prior to treatment. In terms of compliance, patients comply more easily with treatment regimens if they instill eye drops less frequently. ${ }^{3}$ 
Prostaglandin derivatives and prostamides, which are a relatively new class of ocular hypotensive agents, are very effective in lowering IOP. They are biologically active derivatives of arachidonic acid. Arachidonic acid is later converted to prostaglandins, which are normally present in ocular tissues and mediate or modulate a broad spectrum of biological processes. Prostaglandin analogues are a very effective and useful class of drugs in the treatment of glaucoma. They reduce IOP by increasing uveoscleral outflow and to some degree, conventional outflow. Latanoprost, bimatoprost, and travoprost are used once daily and unoprostone is used twice daily. Because very low concentrations are used in glaucoma treatment and the plasma half-life is short, systemic side effects are rare. Conjunctival hyperemia, stinging, burning, eyelash changes, increased iris pigmentation, cystoid macular edema in aphakic and pseudophakic eyes, reactivation of herpes keratitis, and anterior uveitis are local side effects. ${ }^{4}$

Latanoprost is an analogue of prostaglandin $\mathrm{F}_{2 \alpha}$. It reduces IOP very effectively with minimal systemic side effects. Although the underlying mechanism remains unclear, latanoprost lowers IOP by increasing uveoscleral outflow. It was hypothesized that prostaglandins may stimulate collagenase and other metalloproteinases to degrade the extracellular matrix between ciliary muscle bundles. ${ }^{5}$ Studies have reported a $20 \%-40 \%$ decrease in IOP after latanoprost treatment. Ocular hypertension and primary open-angle glaucoma (POAG) patients had a high chance of experiencing a sufficient IOP reduction with latanoprost monotherapy during 2 years of treatment. ${ }^{6}$ This drug has been effective in several glaucoma subtypes. It is used in a $0.005 \%$ concentration. Bimatoprost has been described as a prostamide. It was reported not to be a prostaglandin and does not act on prostanoid receptors. However, binding of bimatoprost to the FP prostanoid receptor, which is the same receptor selectively activated by latanoprost, has been demonstrated. Bimatoprost was shown to be as effective as latanoprost with a higher percentage of conjunctival hyperemia. ${ }^{7}$ It is used in a $0.03 \%$ concentration. Travoprost is a topical ocular ester prodrug that is rapidly hydrolyzed to biologically active free acid structurally similar to other prostaglandin $\mathrm{F}_{2 \alpha}$ analogues. The IOP-lowering effect of travoprost is comparable to latanoprost. ${ }^{8}$ Travoprost is commercially available in a $0.004 \%$ concentration. Unoprostone isopropyl is another prostaglandin $\mathrm{F}_{2 \alpha}$ analogue that was first introduced in Japan. It is administered twice daily in a $0.15 \%$ concentration and has been found to be less effective than other drugs of this class. ${ }^{9}$
Tafluprost (1-methylethyl [5Z]-7-[(1R,2R,3R,5S)-2-[(1E)3,3-difluoro-4-phenoxy-1-butenyl]-3,5-dihydroxycyclopentyl]-5-heptenoate) is a unique 16-phenoxy analogue of prostaglandin $F_{2 \alpha}$ with a 15,15-difluoro substitution, which is clinically used as an ocular hypotensive agent to treat glaucoma and ocular hypertension patients. ${ }^{10,11}$ It was launched on the ophthalmic market in 2008. It is used in a $0.0015 \%$ concentration in single-use containers, dosed once daily in the evening. Tafluprost is an isopropyl ester prodrug that is rapidly hydrolyzed by corneal esterases to the free acid of tafluprost (the active form). In this way, it facilitates corneal penetration. The metabolite of tafluprost, tafluprost acid, has an increased affinity for the prostanoid FP receptor compared to latanoprost. ${ }^{10}$

Topical antiglaucomatous agents are associated with various adverse effects, such as burning, a stinging sensation, tearing, dry eye, and allergic reactions. Discomfort due to medications may affect patients' quality of life and may cause poor compliance. Poor compliance leads to poor IOP control. Glaucoma is a chronic disease requiring lifelong treatment; therefore, to minimize the side effects of long-term treatment, preparations with lower benzalkonium chloride (BAC) concentrations, preservative-free preparations, and alternative preservatives have been developed and have been shown to have a lower rate of side effects. ${ }^{12}$

There is a growing body of evidence demonstrating that some local adverse effects may be the result of preservatives rather than active compounds. BAC is a cationic detergent and the most commonly used preservative in topical ophthalmic preparations. It ranges in concentration from $0.02 \%-0.004 \%$ and is used in approximately three quarters of all eye drops. BAC interacts with membrane proteins and may change the ionic resistance of the cornea by intercalating into the cellular membrane. ${ }^{13}$ It can accumulate in ocular tissues for long periods and may induce cell toxicity in a dose-dependent manner. The detergent effect of BAC may cause loss of tear film stability, toxicity of the corneal and conjunctival epithelium, and immunoallergic reactions. ${ }^{13,14}$ Corneal cell dysfunction and lysis were found to be related to the concentration and duration of exposure. ${ }^{13}$ In vivo application of $0.005 \%$ BAC solution in rabbits caused swelling and desquamating of superficial corneal epithelial cells, demonstrated by scanning confocal microscopy. ${ }^{15}$ It was found that conjunctival cells die by necrosis at high concentrations of BAC and by apoptosis at low concentrations of BAC. ${ }^{16}$ Other ophthalmic preservatives are thiomersal, benzododecinium bromide, cetrimide, EDTA, phenylmercuric nitrate, chlorobutanol, PHBG, sodium perborate, sorbic acid, clorhexidine digluconate, and parahydroxybenzoat. ${ }^{14,17}$ 
Purite, PQ-1, and SofZia are other ophthalmic preservatives designed to eliminate the toxic adverse effects of preservatives.

An ex vivo and in vitro study has demonstrated that preserved formulations of latanaprost and timolol induced higher proinflammatory, proapoptotic, and toxic effects on conjunctival cells than a nonpreserved timolol preparation. ${ }^{18}$ Other adverse effects of BAC include significant instability of precorneal tear film, toxicity to the trabecular meshwork, and an increased rate of failed glaucoma surgery. ${ }^{19-21}$ Reduction in corneal cell proliferation and viability causing epithelial barrier problems, a significant degree of squamous metaplasia, inflammation, and subconjunctival fibrosis have been observed with preservatives even though some of these effects are still being debated. ${ }^{19,22-24}$ There is general acceptance that a change from preserved to nonpreserved preparations was associated with a significant decrease of the signs and symptoms of ocular irritation. Even though BAC was shown to increase the corneal permeability of pharmacological agents, ${ }^{25}$ controversial data exists that BAC and BAC-free formulations have similar efficacy. ${ }^{26}$ BAC was demonstrated to act as an absorption enhancer to improve drug penetration through cellular membranes in the cornea. The absorption of acyclovir increased tenfold with $0.01 \%$ BAC. ${ }^{25}$ However, in a study comparing nonpreserved and preserved $0.1 \% \mathrm{~T}-\mathrm{Gel}$ eye gel, the preservative did not have an effect on the IOP-lowering efficacy. ${ }^{27} \mathrm{BAC}$-free travoprost $0.004 \%$, formulated with the SofZia system, (Travatan $Z^{\circledR}$; Alcon, Hünenberg, Switzerland) was compared to BAC-preserved marketed formulation travoprost $0.004 \%$ (Travatan, Alcon) and was found equivalent in terms of safety and efficacy. ${ }^{26}$ Single-dose unit preservativefree glaucoma medications such as timolol gel $0.1 \%$ and a timolol and dorzolamide combination have been introduced on the ophthalmic market. ${ }^{27}$ Even though single-dose unit eye drops remained free of bacterial contamination for up to 1 day after opening, their cost and difficulty of use for older patients are major disadvantages. ${ }^{17,27}$ Corneal penetration of preserved and nonpreserved formulations of topical tafluprost applications in rabbit eyes were compared. ${ }^{28}$ The penetration of topically applied nonpreserved tafluprost $0.0015 \%$ eye drops into the aqueous humor of rabbits was similar to the penetration of tafluprost $0.0015 \%$ eye drops preserved with $0.01 \%$ BAC. BAC did not have an effect on the corneal penetration of tafluprost into the aqueous humor. ${ }^{28}$

Prostaglandin $\mathrm{F}_{2 \alpha}$ has been known to have antiapoptotic effects in some cell types and tissues. ${ }^{29}$ Tafluprost promoted survival and inhibited apoptotic events in serum-deprived and glutamate-exposed retina ganglion cells in an experimental study where cultured retina ganglion cells and rat retina ganglion cells with optic nerve crash were used. ${ }^{30}$ Tafluprost reduced $\mathrm{Ca}$ in rat retina ganglion cells exposed to glutamate. In glaucoma, excessive amounts of glutamate are considered to be an important factor causing apoptosis in retina ganglion cells. In vivo prostanoid agonists have been found to protect retina ganglion cells from injury, ${ }^{30-32}$ perhaps by suppressing apoptosis through the inhibition of caspase-3 activation. ${ }^{33}$ In one study, the application of tafluprost to retinal explants enhanced retina ganglion cell survival significantly, suggesting a direct neuroprotective ability concomitant with ocular hypotensive effects. ${ }^{34}$

The tissue distribution and metabolism of tafluprost was evaluated in cynomolgus monkeys. ${ }^{35}$ After a single dose of an ophthalmic solution containing $0.0005 \%, 0.005 \%$, or $0.05 \%$ tafluprost was topically instilled ( $20 \mathrm{~mL} / \mathrm{eye}$ ), blood, ocular and systemic tissues, or excreta were collected for 24 hours after the drug instillations. High concentrations of drug-related radioactivity were observed in the cornea and conjunctiva, followed by the iris, sclera, choroid with retina pigment epithelium, and aqueous humor. The highest concentration of radioactivity occurred in ocular tissues within 2 hours after dosing. The measured radioactivity in the tissues was proportional to the administered dose. The major tafluprost metabolites in the ocular tissues were tafluprost acid, 1,2-dinor- and 1,2,3,4-tetaranor-tafluprost acid. The concentration of tafluprost acid in the aqueous humor and ciliary body was enough to stimulate prostanoid FP receptors. The major metabolites were intracamerally injected in order to observe their antiglaucomatous effects. Tafluprost acid was shown to significantly lower the IOP, while 1,2-dinor- and 1,2,3,4-tetaranor-tafluprost acid did not. ${ }^{35}$ Tafluprost was well absorbed to ocular tissues. The major metabolite and only active form of tafluprost acid was further metabolized by $\beta$ oxidation to inactive metabolites. Even though there are no other pathways for metabolic inactivation, tafluprost did not accumulate in tissues. ${ }^{36}$ After both single and multiple topical applications, the plasma concentration of tafluprost remained at low levels. The peak plasma concentration was reached at 10 minutes, and it was detected in plasma for up to 1 hour after topical application. ${ }^{37}$

The ocular hypotensive efficacy of tafluprost has been demonstrated in various preclinical animal studies. Single-dose applications of tafluprost have demonstrated IOP-lowering efficacy in both ocular normotensive and laser-induced ocular hypertensive monkeys. A statistically significant IOP reduction was achieved after a single dose 
of $0.0005 \%$ and $0.0025 \%$ tafluprost when compared to a vehicle. An IOP-lowering efficacy of $0.0025 \%$ tafluprost was greater than $0.005 \%$ latanoprost and $0.0005 \%$ tafluprost was almost equal to $0.005 \%$ latanoprost. ${ }^{10}$ Kurashima et al switched monkeys which had a low susceptibility and an inadequate IOP reduction by latanoprost treatment to tafluprost treatment. It was demonstrated that the IOP reduction induced by tafluprost $0.0015 \%$ (2.4 $\mathrm{mmHg}$ ) was significantly greater than latanoprost $0.005 \%(0.4 \mathrm{mmHg})$ in all monkeys tested. This effect disappeared after switching back to latanoprost. Latanoprost low responders exist among monkeys and these results suggested that tafluprost may be effective for latanoprost nonresponder patients. ${ }^{38}$ The IOP-lowering effect and mechanism of action was studied in prostanoid receptor-deficient mice. It was concluded that tafluprost lowers IOP through the prostanoid FP receptor. Part of the ocular hypotensive effect of tafluprost was attributed to FP receptor-mediated prostaglandin production acting through the prostanoid EP3 receptor. ${ }^{39}$

The pharmacodynamics, safety, and tolerability of tafluprost were evaluated in various clinical studies. The efficacy, safety, and tolerability of tafluprost $0.0015 \%$ were compared to the efficacy, safety, and tolerability of latanoprost $0.005 \%$ in patients with POAG, exfoliation glaucoma, or ocular hypertension in a randomized, doublemasked, active-controlled, parallel-group, multinational and multicenter phase II study. Maximum IOP reduction was achieved by day 7 and was sustained in both groups. Tafluprost and latanoprost had comparable effects on the extent, duration, and stability of IOP reduction, and were well tolerated in patients. ${ }^{40}$ The long-term efficacy and safety of tafluprost $0.0015 \%$ were compared to long-term efficacy and safety of latanoprost $0.005 \%$ eye drops in patients with POAG or ocular hypertension in a doublemasked, active-controlled, parallel-group, multinational, multicenter, phase III study conducted at 49 centers in eight countries. Both treatments had a substantial IOP-lowering effect that persisted throughout the study $(-7.1 \mathrm{mmHg}$ for tafluprost and $-7.7 \mathrm{mmHg}$ for latanoprost at 24 months). Although the IOP-lowering effect was slightly greater with latanoprost, the difference was clinically small and the noninferiority of tafluprost to latanoprost over all diurnal IOP measurements was shown. Both drugs were well tolerated and adverse events were mild to moderate. The most frequently reported adverse effect was conjunctival hyperemia. The stimulating effect on eyelash growth was absent or mild in $90 \%$ of patients in both groups after 24 months. More cases of iris pigmentation were reported in the latanoprost group (28\%) than in that treated with tafluprost $(26.1 \%)$, but the differences were not significant. ${ }^{41}$ The pharmacokinetics and efficacy of preserved and preservative-free tafluprost $0.0015 \%$ were evaluated in a randomized, investigatormasked, multicenter, crossover phase III study. The drugs were administered for 4 weeks in 43 patients with POAG or ocular hypertension. After 4 weeks, no significant difference in pharmacokinetic parameters between the formulations after single or repeated dosing was observed. Ocular hyperemia occurred with the same frequency in both groups, but was predominantly of moderate severity in eyes treated with preserved tafluprost, compared to only mild severity with the preservative-free formulation. ${ }^{37}$ In another study, the diurnal IOP-lowering efficacy and safety of travoprost $0.004 \%$ and tafluprost $0.0015 \%$ was compared. The drugs were administered to patients with POAG or ocular hypertension in a randomized, doublemasked, active-controlled, crossover design trial for six weeks and then the alternative treatment was administered for a subsequent six weeks. The 12-hour mean diurnal IOP was significantly lower with travoprost than with tafluprost $(16.9 \mathrm{mmHg}$ versus $17.5 \mathrm{mmHg})$. Neither treatment produced a significant increase from baseline in light sensitivity, blurred-dim vision, stinging/burning, foreign body sensation, or pain. Hyperemia was increased with both therapies. Investigator-observed hyperemia was also significantly increased from baseline for both travoprost and tafluprost. The increase with travoprost treatment was significantly smaller than with tafluprost. ${ }^{42}$

Abnormal vascular regulation has been suggested to be involved in the development of POAG. Studies have shown decreased optic nerve head $(\mathrm{ONH})$ and retinal blood flow in patients with POAG. The short-term effect of topical tafluprost on feline retinal circulation was investigated using a laser Doppler velocimetry system. Tafluprost $0.0015 \%$ significantly increased retinal blood flow and blood velocity for 120 minutes after instillation, while there was no significant change in vessel diameter. ${ }^{43}$ Akaishi compared the effects of repeated administrations of three prostaglandin $\mathrm{F}_{2 \alpha}$ analogs (tafluprost, latanoprost, and travoprost) on $\mathrm{ONH}$ blood flow in normal rabbits using laser speckle flowgraphy. They found that ONH blood flow increased after 28 days of treatment with any of the three agents. The effect of tafluprost was significantly greater than that seen with travoprost and tended to be greater than that seen with latanoprost. ${ }^{44}$ Another study investigated the effects of topically administered tafluprost $0.0015 \%, 15$-hydroxyl tafluprost (15-OH tafluprost) $0.0015 \%$, latanoprost $0.005 \%$, or travoprost $0.004 \%$ on 
ONH blood flow and on endothelin-1-induced contractions in isolated rabbit ciliary artery segments. All therapies relaxed the endothelin-1-induced ciliary artery contractions. Improvement of the ocular circulation seemed superior with tafluprost compared with the other prostaglandin $\mathrm{F}_{20}$ analogs. ${ }^{45}$

Ocular surface and impression cytology samples have been compared between tafluprost and other prostaglandin analog therapies. Uusitalo et al investigated whether patients who exhibit limited tolerability to latanoprost benefited from switching to preservative-free prostaglandin tafluprost. Throughout the treatment period of 3 months, the drugs were equally effective. There was a dramatic decrease in the number of patients exhibiting subjective symptoms during preservative-free tafluprost treatment (around 50\% compared to latanoprost at baseline), and a decrease in most of the signs of ocular side effects.

The decrease in the number of patients with abnormal levels of HLA-DR-positive conjunctival epithelial cells and with abnormal levels of MUC5AC-expressing goblet cells after preservative-free tafluprost treatment when compared to preserved latanoprost at baseline indicates less harmful effects on the conjunctiva during treatment with a preservative-free prostaglandin solution. Preservative-free tafluprost caused less conjunctival hyperemia than the latanoprost. Hyperemia with the use of the commercially available latanoprost formulation may partly be caused by the very high concentration of BAC. Preservative-free tafluprost was better tolerated than the commercially available formulation of latanoprost in patients who exhibited ocular surface side effects during latanoprost treatment at the baseline visit. ${ }^{46}$

In another study, conjunctival and corneal reactions of commercially available latanoprost and preservative-free tafluprost were compared in rabbit eyes. The rabbits received phosphate buffered saline, preservative-free tafluprost $0.0015 \%$, latanoprost $0.005 \%$, or BAC $0.02 \%$. All solutions were applied at 5-minute intervals for a total of 15 times. There were higher expressions of CD45+ and TNFR1+ in latanoprost- or BAC-instilled groups compared with preservative-free tafluprost and saline groups. Latanoprost induced fewer positive cells for inflammatory marker expressions in specimens compared with BAC alone, both of which were higher than with preservative-free tafluprost or saline. Immunohistology showed the same tendency of toxic ranking. ${ }^{47}$

In conclusion, preservative-free tafluprost is a promising new prostaglandin agent in the treatment of glaucoma.

\section{Disclosure}

The author reports no conflicts of interest in this work.

\section{References}

1. Goldberg I. Relationship between intraocular pressure and preservation of visual field in glaucoma. Surv Ophthalmol. 2003;48(Suppl 1): S3-S7.

2. The Advanced Glaucoma Intervention Study (AGIS): 7. The relationship between control of intraocular pressure and visual field deterioration. The AGIS Investigators. Am J Ophthalmol. 2000;130:429-440.

3. Soltau JB, Zimmerman TJ. Changing paradigms in the medical treatment of glaucoma. Surv Ophthalmol. 2002;47(Suppl 1):S2-S5.

4. Weitzman M, Caprioli J. Medical Therapy of Glaucoma. In: Tasman W, Jaeger EA, editors. Duane's Ophthalmology. Philadelphia, PA: Lippincott Williams and Wilkins. [CD-ROM]; 2002.

5. Tamm E, Rittig M, Lutjen-Drecoll E. Electron microscopy and immunohistochemical studies of the intraocular pressure lowering effect of prostaglandin F2 alpha. Fortschr Ophthalmol. 1990;87:623-629.

6. Hedman K, Watson PG, Alm A. The effect of latanoprost on intraocular pressure during 2 years of treatment. Surv Ophthalmol. 2002;47(Suppl 1): S65-S76.

7. Eisenberg DL, Toris CB, Camras CB. Bimatoprost and travoprost: a review of recent studies of two new glaucoma drugs. Surv Ophthalmol. 2002;47(Suppl 1):S105-S115.

8. Netland PA, Landry T, Sullivan EK, et al. Travoprost Study Group. Travoprost compared with latanoprost and timolol in patients with openangle glaucoma or ocular hypertension. Am J Ophthalmol. 2001;32: 472-484.

9. Saito M, Takano R, Shirato S. Effects of latanoprost and unoprostone when used alone or in combination for open-angle glaucoma. Am J Ophthalmol. 2001;132:485-489.

10. Takagi Y, Nakajima T, Shimazaki A, et al. Pharmacological characteristics of AFP-168 (tafluprost), a new prostanoid receptor FP agonist, as an ocular hypotensive drug. Exp Eye Res. 2004;78:767-776.

11. Aihara M. Clinical appraisal of tafluprost in the reduction of elevated intraocular pressure (IOP) in open-angle glaucoma and ocular hypertension. Clin Ophthalmol. 2010;4:163-170.

12. Noecker RJ, Herrygers LA, Anwaruddin R. Corneal and conjunctival changes caused by commonly used glaucoma medications. Cornea. 2004;23:490-496.

13. Cha SH, Lee JS, Oum BS, Kim CD. Corneal epithelial cellular dysfunction from benzalkonium chloride (BAC) in vitro. Clin Experiment Ophthalmol. 2004;32:180-184.

14. Debbasch C, Brignole F, Pisella PJ, Warnet JM, Rat P, Baudouin C. Quaternary ammoniums and other preservatives' contribution in oxidative stress and apoptosis on Chang conjunctival cells. Invest Ophthalmol Vis Sci. 2001;42:642-652.

15. Ichijima H, Petroll WM, Jester JV, Cavanagh HD. Confocal microscopic studies of living rabbit cornea treated with benzalkonium chloride. Cornea. 1992;11:221-225.

16. De Saint Jean M, Brignole F, Bringuier AF, Bauchet A, Feldmann G, Baudouin C. Effects of benzalkonium chloride on growth and survival of Chang conjunctival cells. Invest Ophthalmol Vis Sci. 1999;40:619-630.

17. Noecker R. Effects of common ophthalmic preservatives on ocular health. Adv Ther. 2001;18:205-215.

18. Pisella PJ, Debbasch C, Hamard P, et al. Conjunctival proinflammatory and proapoptotic effects of latanoprost and preserved and unpreserved timolol: an ex vivo and in vitro study. Invest Ophthalmol Vis Sci. 2004;45:1360-1368.

19. Ishibashi T, Yokoi N, Kinoshita S. Comparison of the short-term effects on the human corneal surface of topical timolol maleate with and without benzalkonium chloride. J Glaucoma. 2003;12:486-490.

20. Samples JR, Binder PS, Nayak S. The effect of epinephrine and benzalkonium chloride on cultured corneal endothelial and trabecular meshwork cells. Exp Eye Res. 1989;49:1-12. 
21. Baudouin C. Side effects of antiglaucomatous drugs on the ocular surface. Curr Opin Ophthalmol. 1996;7:80-86.

22. De Saint Jean M, Debbasch C, Brignole F, Rat P, Warnet JM, Baudouin C. Toxicity of preserved and unpreserved antiglaucoma topical drugs in an in vitro model of conjunctival cells. Curr Eye Res. 2000;20:85-94.

23. Hong S, Lee CS, Seo KY, Seong GJ, Hong YJ. Effects of topical antiglaucoma application on conjunctival impression cytology specimens. Am J Ophthalmol. 2006;142:185-186.

24. Baudouin C, Hamard P, Liang H, Creuzot-Garcher C, Bensoussan L, Brignole F. Conjunctival epithelial cell expression of interleukins and inflammatory markers in glaucoma patients treated over the long term. Ophthalmology. 2004;111:2186-2192.

25. Majumdar S, Hippalgaonkar K, Repka MA. Effect of chitosan, benzalkonium chloride and ethylenediaminetetraacetic acid on permeation of acyclovir across isolated rabbit cornea. Int $J$ Pharm. 2008;348:175-178.

26. Lewis RA, Katz GJ, Weiss MJ, et al; Travoprost BAC-free Study Group. Travoprost $0.004 \%$ with and without benzalkonium chloride: a comparison of safety and efficacy. J Glaucoma. 2007;16: 98-103.

27. Easty DL, Nemeth-Wasmer G, Vounatsos JP, et al. Comparison of a non-preserved $0.1 \% \mathrm{~T}-\mathrm{Gel}$ eye gel (single dose unit) with a preserved $0.1 \% \mathrm{~T}-\mathrm{Gel}$ eye gel (multidose) in ocular hypertension and glaucomatous patients. Br J Ophthalmol. 2006;90:574-578.

28. Pellinen P, Lokkila J. Corneal penetration into rabbit aqueous humor is comparable between preserved and preservative-free tafluprost. Ophthalmic Res. 2009;41:118-122.

29. Cazevieille C, Muller A, Meynier F, Dutrait N, Bonne C. Protection by prostaglandins from glutamate toxicity in cortical neurons. Neurochem Int. 1994;24:395-398.

30. Kanamori A, Naka M, Fukuda M, Nakamura M, Negi A. Tafluprost protects rat retinal ganglion cells from apoptosis in vitro and in vivo. Graefes Arch Clin Exp Ophthalmol. 2009;247:1353-1360.

31. Kanamori A, Naka M, Fukuda M, Nakamura M, Negi A. Latanoprost protects rat retinal ganglion cells from apoptosis in vitro and in vivo. Exp Eye Res. 2009;88:535-541.

32. Kudo H, Nakazawa T, Shimura M, et al. Neuroprotective effect of latanoprost on rat retinal ganglion cells. Graefes Arch Clin Exp Ophthalmol. 2006;244:1003-1009.

33. Nakanishi Y, Nakamura M, Mukuno H, Kanamori A, Seigel GM, Negi A. Latanoprost rescues retinal neuro-glial cells from apoptosis by inhibiting caspase-3, which is mediated by p44/p42 mitogenactivated protein kinase. Exp Eye Res. 2006;83:1108-1117.

34. Bull ND, Johnson TV, Welsapar G, DeKorver NW, Tomarev SI, Martin KR. Use of an adult rat retinal explant model for screening of potential retinal ganglion cell neuroprotective therapies. Invest Ophthalmol Vis Sci. 2011;52:3309-3320.
35. Fukano Y, Kawazu K, Akaishi T, Bezwada P, Pellinen P. Metabolism and ocular tissue distribution of an antiglaucoma prostanoid, tafluprost, after ocular instillation to monkeys. J Ocul Pharmacol Ther. 2011;27:251-259.

36. Fukano Y, Kawazu K. Disposition and metabolism of a novel prostanoid antiglaucoma medication, tafluprost, following ocular administration to rats. Drug Metab Dispos. 2009;37:1622-1634.

37. Uusitalo H, Kaarniranta K, Ropo A. Pharmacokinetics, efficacy and safety of preserved and preservative-free tafluprost in healthy volunteers. Acta Ophthalmol Suppl (Oxf). 2008;242:S7-S13.

38. Kurashima H, Asai Y, Aihara M, Ishida N, Nakamura M, Araie M. Ocular hypotensive effect of tafluprost in latanoprost low-responder cynomolgus monkeys. J Glaucoma. 2012;21:123-128.

39. Ota T, Aihara M, Saeki T, et al. The IOP-lowering effects and mechanism of action of tafluprost in prostanoid receptor-deficient mice. $\mathrm{Br} J$ Ophthalmol. 2007;91:673-676.

40. Traverso CE, Ropo A, Papadia M, et al. A Phase II study on the duration and stability of the intraocular pressure-lowering effect and tolerability of tafluprost compared with latanoprost. J Ocul Pharmacol Ther. 2010;26:97-104.

41. Uusitalo H, Pillunat LE, Ropo A. Efficacy and safety of tafluprost $0.0015 \%$ versus latanoprost $0.005 \%$ eye drops in open-angle glaucoma and ocular hypertension: 24-month results of a randomized, doublemasked phase III study. Acta Ophthalmol. 2010;88:12-19.

42. Schnober D, Hofmann G, Maier H, Scherzer ML, Ogundele AB, Jasek MC. Diurnal IOP-lowering efficacy and safety of travoprost $0.004 \%$ compared with tafluprost $0.0015 \%$ in patients with primary open-angle glaucoma or ocular hypertension. Clin Ophthalmol. 2010;8:1459-1463.

43. Izumi N, Nagaoka T, Sato E, et al. Short-term effects of topical tafluprost on retinal blood flow in cats. J Ocul Pharmacol Ther. 2008;24: 21-526.

44. Akaishi T, Kurashima H, Odani-Kawabata N, Ishida N, Nakamura M. Effects of repeated administrations of tafluprost, latanoprost, and travoprost on optic nerve head blood flow in conscious normal rabbits. J Ocul Pharmacol Ther. 2010;26:181-186.

45. Kurashima H, Watabe H, Sato N, Abe S, Ishida N, Yoshitomi T. Effects of prostaglandin $\mathrm{F}(2 \alpha)$ analogues on endothelin-1-induced impairment of rabbit ocular blood flow: comparison among tafluprost, travoprost, and latanoprost. Exp Eye Res. 2010;91:853-859.

46. Uusitalo H, Chen E, Pfeiffer N, et al. Switching from a preserved to a preservative-free prostaglandin preparation in topical glaucoma medication. Acta Ophthalmol. 2010;88:329-336.

47. Liang H, Baudouin C, Pauly A, Brignole-Baudouin F. Conjunctival and corneal reactions in rabbits following short- and repeated exposure to preservative-free tafluprost, commercially available latanoprost and $0.02 \%$ benzalkonium chloride. $\mathrm{Br} J$ Ophthalmol. 2008;92:1275-1282.
Clinical Ophthalmology

\section{Publish your work in this journal}

Clinical Ophthalmology is an international, peer-reviewed journal covering all subspecialties within ophthalmology. Key topics include: Optometry; Visual science; Pharmacology and drug therapy in eye diseases; Basic Sciences; Primary and Secondary eye care; Patient Safety and Quality of Care Improvements. This journal is indexed on Submit your manuscript here: http://www.dovepress.com/clinical-ophthalmology-journal

\section{Dovepress}

PubMed Central and CAS, and is the official journal of The Society of Clinical Ophthalmology (SCO). The manuscript management system is completely online and includes a very quick and fair peer-review system, which is all easy to use. Visit http://www.dovepress.com/ testimonials.php to read real quotes from published authors. 